\title{
シェル的構造物の自由振動特性に及ぼす初期応力の 影響に関する推定法
}

\section{ESTIMATION ON THE EFFECT OF INITIAL STRESSES ON THE FREE VIBRATION BEHAVIOR OF SHELL-LIKE STRUCTURES}

\author{
山田聖志*, 竹内明子** \\ Seishi YAMADA and Akiko TAKEUCHI
}

\begin{abstract}
An alternative simple analytical procedure is presented for the estimation of the reduction of the free vibration frequency of shells or shell-like spaceframes due to initial pre-compressed stresses. Then it is: applied to latticed cylindrical roof structures through orthotropic shell analogy and the results are compared with fully finite element eigenvalue analytical results. It is suggested that it is possible to predict an alternative lower bound to imperfection sensitivity for the free vibration frequency of shell-like structures by applying the so-called reduced stiffness buckling modeling.
\end{abstract}

Keywords : latticed shell, initial stress, linear buckling analysis, free vibration, initial imperfections ラチスシェル, 初期応力, 線形座屈解析, 自由振動, 初期不整

\section{1.はじめに}

薄肉シェル屋根構造やスペースフレーム曲面状のいわ ゆるシェル的構造物では，静的座届安定性の検討が構造 設計上の主たる課題とされ，多くの研究成果が得られて

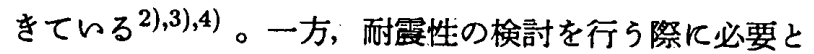
なる基本的振動性状について，乙の種の構造物に対して は，必ずしも十分な成果が得られている状沇にはないと 考える。特に, 自重・積載・積雪等によって振動開始前 に存在している初期応力が, 座届荷重時での応力に対し て, どの程度のレベルにあるとを，その初期応力を無視 して得られた振動特性值に比して，どの程度異なるもの なのかの十分な議論は, なされていないようである。静 的座屈解析で得られる性状との相互関係が理解しやすい 振動解析手順は，こらした課題の検討に非常に有用であ ると考えられる。

以上の観点に立ち，2.1節では, 予め線形座届固有 值解析で得られる複数の座届モード（以下，これらを「 座屆モード群」と呼ぶ）を，利用した非減衰自由振動ス ペクルル近似解析手法を提案している。との手法は，エ ネルギーのレーリー商5) を応用したものである。てれに よって得られる固有振動数は, 静的座屈問題での古典座 届値に相当し, 初期不整の存在によって低下すると予想 される值の上限を与えると考えられる。第 3 章で適用例. として用らる部分円筒ラチスシェルのよ5K, 座届前に
顕著な非線形変形性状を示し，座屈荷重が線形座屈固有 値解析で得られる値よりかなり低くなるような構造物で $は^{4), 6)}$ 特に, 固有振動数解析においてもその低下の程度 を把握するととは重要であると考えられる。そとで2， 2 節では, その低下の下限を簡便に評価する手法として, 静的座届問題で発展した低減剛性 (Reduced Stiffness: 以下「RS」と略す）モデル7),8) を，新たに動的問題に 適用する方法を提案し， 3.4 節で平行して行われる有 限要素法による精密な数値解析結果との比較を通して, 本手法の適用性についての検討も試みる。

\section{2. 解析方法}

\section{1 座屆モード群を利用した自由振動解析法}

シェルおよびシェル的構造物を, 調和関数等を用いて 関数離散化を行なったり，あるんは有限要素法で領域型 離散化を行々，有限自由度系としてモデル化すると，そ の静的座届に関する基本的な特性が線形座屈固有值解析 によって得られることは良く知られている。こらした多 自由度系の線形座届固有值解析からは, 仮定した自由度 だけの座届荷重 $q_{c}$ が固有值として，また各々に対応する 座届モード $\{u\} か ゙$ 固有モードとして計算できる。得られ た各坐屈モード $\{u\} に$ 対して，それぞれ次式が恒等的に 成立する ${ }^{9)}$ 。

\footnotetext{
本論文の一部は文献 1)で発表している。

$*$ 豊橋技術科学大学建設工学系 助教授 $\cdot$ 工博

** 豊橋技術科学大学建設工学系 大学院生
}

Assoc. Prof., Dept. of Architecture and Civil Eng., Toyohashi Univ. of Technology, Dr. Eng.

Graduate Student, Dept. of Architecture and Civil Eng., Toyohashi Univ. of Technology 


$$
U_{2 b}+U_{2 m}+V_{2 m}=0
$$

ことで, $U_{2 b}$ は曲げひずみの座届変位に関する線形成分か ら計算される，いわゅる線形曲げひずみエネルギー， $U_{2 m}$ は, 面内ひずみの座届変位に関する線形成分から計 算される，いわゆる線形面内ひずみエネルギーである。 $V_{2 m}$ は, 面内ひずみの座届変位几関する 2 次の非線形成 分と座届前の基本平衡状熊時の応力との積から計算され る，らわゆる線形化された面内ひずみエネルギーである。 線形座届固有值解析では, 座屈前の基本平衡状態は線形 応力状態として仮定されるので， $V_{2 m}$ は次のように書け る。

$$
V_{2 m}=-Q_{c} \alpha_{m}
$$

ととK $Q_{c} \equiv q_{c} / q_{d}$ で, 座屈荷重 $q_{c}$ を正規化するための値 $q_{d}$ Kは，設計荷重値あるいは $q_{c}$ の最小值など，目的飞応 じて任意に設定できる。 $\alpha_{m}$ は各座届モードに対して, 部材剛性等の既知の諸量から計算できる係数である。

次 $K, q_{d}$ のQ倍の静的荷重値 $q=Q q_{d}$ のもとで平衡状 態にあるシェル的構造物が，十分微小な振動を開始し， それが非減衰定常状態となった自由振動状態を想定する。 との静的荷重值 $q$ にって生じる初期応力を考慮して, 振動問題を扱 5 K際し, ある振動モードがk次の座屈モ 一ドに近似でをるとき，運動に関する良く知られたラグ ランジェの関係式から，次の式が得られる。

$$
T_{2}-\left(U_{2 b}+U_{2 m}-Q \alpha_{m}\right)=0
$$

ことに第 1 項の $T_{2}$ は，速度 $\{\dot{u}\} \equiv\{\partial u / \partial \tau\}$ についての最 大運動エネルギーを意味している。ては時間を表わす。 第 2 項の括弧内は, 最大ポテンシャルエネルギーに相当 する。との場合, 各モードに対応する固有円振動数を $\omega$ とすると， $T_{2}$ は，次のよ5におくととができる。

$$
T_{2}=\omega^{2} \alpha_{t}
$$

ことで， $\alpha_{t}$ は，対象としているモードに対して，既知の 諸量から計算できる係数である。

一般K，非減衰自由振動モードが静的座屈モードに必 ずしも等しいとは言えない。しかし振動開始前の静的荷

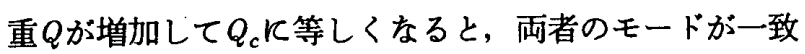
するととは自明である。静的荷重Qが座届荷重の最小值 以下であっても, 非常に多くの坐屈モードを対象にすれ ば，真の自由振動モードに近似するモードを得るてとが 可能であると考えられ，レーリ一商を用いた近似固有振 動数5）と同程度の工学的近似解を得られることが期待で きる。以上の仮定のもとで(1)式と (3)式を連立させると 次式が得られる。

$$
\omega^{2}=\left(Q_{c}-Q\right) \frac{\alpha_{m}}{\alpha_{t}}
$$

シェル的構造物の構造設計においては, 通常, 先ず静 的荷重に対する応力解析や來屈解析を通して, 而力の検 討が行われる。との種の構造物の特徵は, 最小座屈荷重 の近傍に全く異なる來屈モードが存在する可能性を有し ているてとである。こらした複数の座屈モードに対する 初期不整敏感性を非線形解析的飞検討する際, 線形固有 値解析から得られる座届荷重及び R S 荷重スペクトルを 参考にするととは，ての種の構造物の複雑な座屈性状の 力学的理解に, 極めて有益であるととが文献[4]で明らか。 にされている。てれら静的座届に対する検討段階で得ら れた複数の座屈モードを，(5)式に代入すると直接的か つ容易に，自由振動数スペクトルを得るととができる。 その結果は, 静的座屈性状と動的基本振動性状との相互 関係の理解を促進し，引を続いて行われるであろら難解 な地震応答性状の予測等に対して，極めて有用な参考資 料になり得ると期待される。

\section{2 初期不整による座屈耐力の低下が固有振動数に 及ぼす影響の分析手法の提案}

建築大空間屋根棈造でしばしば用いられる偏平球形シ ェルや部分円筒シェル並びに部分円筒ラチスシェルでは, 初期不整のない完全な形状の場合でも，座屈前に非線形 なたわみ性状を示し，座屈荷重が線形座屈固有值解析で

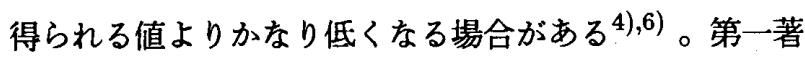
者 $^{8), 3)}$ は, こらした現象を境界支持部の応力かく乱に起 因する「荷重不整(loading imperfection)」と称し，乙れ を等価を形状初期不整に換算する考え方を示し，結果と して, 弾性座届下限荷重 $q_{b}$ を解析する R S 法が, 乙の種 の構造物に対しても適用可能であるてとを明らかにして らる。一方, 弾塑性座屈問題飞対しても， R S 法を利用 するため，文献[7]で「不整型R S モデル」が提案され， 文献[10]では非線形数值解析との対応からその適用性が 検討されている。とうした成果を踏をえ，初期不整に起 因する坐屈耐力の低下が自由振動数に及ぼす影響の程度 を分析するためK，本研究では，弾性 R S 解析結果を応 用する手法を提案する。

初期不整の比較的大きいシェル構造物では, ある座届 変位成分の曲げ変形が他の成分に比して卓越し, 結果と して, 來届耐力 (弾性座届荷重) は, $Q_{r}$ K低下するも のと考える。とのときの変位振幅 $w^{r}{ }_{m n}$ として, 初期不整 振幅 $w^{0}{ }_{m n}$ を用いた陽な形の式を設定してモデル化を行い， それを不整型R Sモデルと呼ぶてととする。文献[7]では, 外压を受ける円筒シェルに対して，次式で表わされる初 期不整を有する压縮柱材の厳密解が採用されている。

$$
w_{m n}^{r}=w_{m n}^{0} \frac{Q}{Q_{r}-Q}
$$

ところで, Virgin ${ }^{11)}$ は, 初期不整を有する区縮柱材の 
振動解析を行い, 非减衰自由振動数の 2 乗が座届变位振 幅の 2 乗に比例するととを示している（文献[11]の(41) 式参照）。シェル的構造物でも，固有振動数と座屈変位 振幅との間には, 形式的にとの関係が成立するものと仮 定すると, 初期不整を有する場合の自由振動数 $\omega_{r}$ は,

$$
\omega_{r}^{2}=a_{0}+a_{1}\left(w_{m n}^{r}\right)^{2}
$$

(6)式を(7)式に代入し，未知の $a_{0}$ と $a_{1}$ を定めるために，

$$
\omega_{r}=\omega \text { for } Q=0, \quad \omega_{r}=0 \text { for } Q=Q_{r}
$$

の条件を用致と，初期不整による座屈耐力の低下を考 慮した固有冈振動数の最も簡潔な表現として, 次式を得 るととができる注1)。

$$
\omega_{r}=\omega \sqrt{1-\left(Q / Q_{r}\right)^{2}}
$$

ことで，右辺のいは，初期不整による座届耐力の低下を 考慮しない場合の円振動数で，その值は(5)式を用いる と容易に計算できる。

(5)式や(9)式で必要な係数 $\alpha_{m}, \alpha_{t}, Q_{c}, Q_{r}$ は, 有限要素法 で数值的に求めるてとももちろん可能である。本推定法 が実設計で使用される場合には, 有限要素法で求める方 が沉用的で便利であろう。本研究では，本推定法のもう 一つの特徵である簡潔さを強調する目的で，筆者らがて れまで静的問題で扱ってきた屋根型の偏平な冈筒ラチス シェル構造物の場合を適用例として選び，連続体置換法 を併用するととで陽な形の推定式が得られるととを次章 で示す。更に，(5)式や(9)式を用いない自由振動解析を， 有限要素法を用いて別途几平行して行い，それらと本推 定法による結果との対応関係について言及する。

\section{3.部分円筒ラチスシェルの自由振動問題への適用 3.1 解析対象}

図1 a に示すように，部材を正三角形に剛接合した単

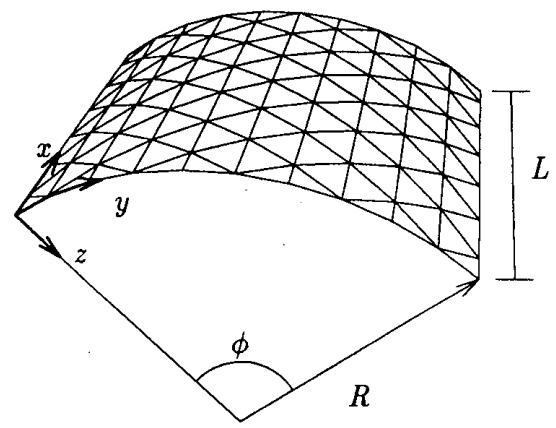

図 1 a 部分円筒ラチスシェルの形状
位ユニットを持ち, 母線方向長さ $L$, 曲率半径 $R$, 開角 $\phi$ の部分円简形の単層ラチスフレーム構造を考える。

\section{2 直交異方性連続体置換を用いた静的座届解析}

山田大彦 ${ }^{12)}$ は，球形の単層ラチスシェルを直交異方 性連続体シェルに置換し，その座届解析を行い，剛性比 や形状係数等のバラメータが座届特性に及仿す影響を系 統的に分析している。本節でも同様の置換法を用いる。

薄肉偏平な円筒形シェルK静的法線方向荷重 $q か ゙$ 作用 するとき，振動開始前の初期応力は近似的に，

$$
\left(N_{x}{ }^{F}, N_{y}{ }^{F}, N_{x y}{ }^{F}\right)=(0,-q R, 0)
$$

なる一様膜応力状熊にあると考えられる。とらしたシェ ルとしての理想的な基本平衡状態をもつ力学モデルを, 文献[8],[3]では理想モデル(idealized model) と呼んでいる。 本節では, 種々のパラメータが やすくするととを目的として，直交異方性連続体置換を 用いた座屈解析を行い，(5)式で自由振動数を計算する 際に必要な $Q_{c}$ を陽な式で求める。

図 $1 \mathrm{a}$ の円筒座標系 $(x, y, z)$ 凡対して構成方程式を, 次 式とする。

$$
\begin{gathered}
M_{x}=D_{x} \rho_{x}+D_{p} \rho_{y}, M_{y}=D_{p} \rho_{x}+D_{y} \rho_{y}, M_{x y}=D_{x y} \kappa_{x y}(10 \mathrm{a}) \\
N_{x}=C_{x} \varepsilon_{x}+C_{p} \varepsilon_{y}, N_{y}=C_{p} \varepsilon_{x}+C_{y} \varepsilon_{y}, N_{x y}=C_{x y} \gamma_{x y}(10 \mathrm{~b})
\end{gathered}
$$

ここに, $\left(M_{x}, M_{y}, M_{x y}\right)$ は曲げモーメント， $\left(N_{x}, N_{y}, N_{x y}\right)$ は 面内合応力， $\left(\rho_{x}, \rho_{y}, \kappa_{x y}\right)$ は曲げひずみ成分, $\left(\varepsilon_{x}, \varepsilon_{y}, \gamma_{x y}\right)$ は 面内ひずみ成分である。をた， $\left(D_{x}, D_{p}, D_{y}, D_{x y}\right)$ は等価な 曲げ岡性， $\left(C_{x}, C_{p}, C_{y}, C_{x y}\right)$ は等価な面内剛性であり, 文 献[13],[14] を参考に本構造物に対して誘導した結果は, 付録に示されている。

上述の一様膜応力状態でのひずみ成分は,

$$
\left(\varepsilon_{x}{ }^{F}, \varepsilon_{y}{ }^{F}, \gamma_{x y}{ }^{F}\right)=\left(\frac{C_{p} q R}{C_{x} C_{y}-C_{p}{ }^{2}}, \frac{C_{x} q R}{C_{p}{ }^{2}-C_{x} C_{y}}, 0\right)
$$

である。この基本平衡状態から座屈するととによって付 加される, $(x, y, z)$ 方向の変位を $(u, v, w)$ とすると, 卜 ータルのひずみは次式のように書ける。
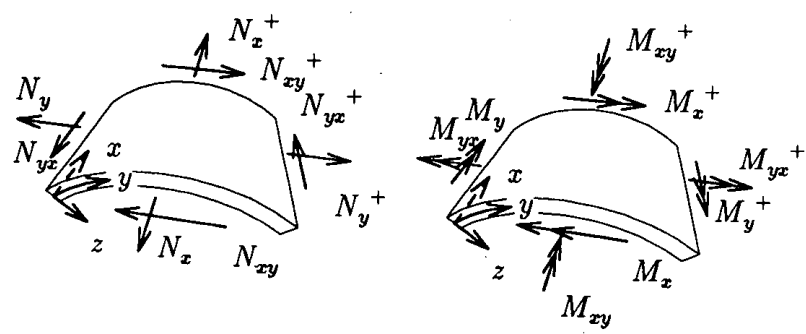

図 $1 \mathrm{~b}$ 連続体解析に打ける合応力の定義 


$$
\begin{gathered}
\rho_{x}=\rho_{x}{ }^{\prime}, \rho_{y}=\rho_{y}{ }^{\prime}, \kappa_{x y}=\kappa_{x y}{ }^{\prime}, \varepsilon_{x}=\varepsilon_{x}{ }^{F}+\varepsilon_{x}{ }^{\prime}+\varepsilon_{x}{ }^{\prime}, \\
\varepsilon_{y}=\varepsilon_{y}{ }^{F}+\varepsilon_{y}{ }^{\prime}+\varepsilon_{y}{ }^{\prime}{ }^{\prime}, \gamma_{x y}=\gamma_{x y}{ }^{\prime}+\gamma_{x y}{ }^{\prime},
\end{gathered}
$$

とこで,

$$
\begin{gathered}
\rho_{x}^{\prime}=-\frac{\partial^{2} w}{\partial x^{2}}, \rho_{y}^{\prime}=-\frac{\partial^{2} w}{\partial y^{2}}, \kappa_{x y}^{\prime}=-2 \frac{\partial^{2} w}{\partial x \partial y} \\
\varepsilon_{x}^{\prime}=\frac{\partial u}{\partial x}, \varepsilon_{y}^{\prime}=\frac{\partial v}{\partial y}-\frac{w}{R}, \gamma_{x y}^{\prime}=\frac{\partial u}{\partial y}+\frac{\partial v}{\partial x} \\
\varepsilon_{x}^{\prime \prime}=\frac{1}{2}\left(\frac{\partial w}{\partial x}\right)^{2}, \varepsilon_{y}^{\prime \prime}=\frac{1}{2}\left(\frac{\partial w}{\partial y}\right)^{2}, \gamma_{x y}^{\prime}{ }^{\prime}=\frac{\partial w}{\partial x} \frac{\partial w}{\partial y}
\end{gathered}
$$

一方, トータルの合応力も，(11)式と同様, 次のよ5 な成分に分解するととができる゙す

$$
\begin{gathered}
M_{x}=M_{x}{ }^{\prime}, M_{y}=M_{y}{ }^{\prime}, M_{x y}=M_{x y}{ }^{\prime}, \\
N_{x}=N_{x}{ }^{\prime}+N_{x}{ }^{\prime}, N_{y}=N_{y}{ }^{F}+N_{y}{ }^{\prime}+N_{y}{ }^{\prime}{ }^{\prime}, \\
N_{x y}=N_{x y}{ }^{\prime}+N_{x y}{ }^{\prime},
\end{gathered}
$$

(1)式を座㐿変位 $u, v, w て ゙$ 変分すると次の平衡方程 式が導かれる。

$$
\begin{array}{r}
\frac{\partial N_{x}^{\prime}}{\partial x}+\frac{\partial N_{x y}^{\prime}}{\partial y}=0 \\
\frac{\partial N_{y}^{\prime}}{\partial y}+\frac{\partial N_{x y}^{\prime}}{\partial x}=0 \\
\frac{\partial^{2} M_{x}^{\prime}}{\partial x^{2}}+\frac{\partial^{2} M_{y}^{\prime}}{\partial y^{2}}+2 \frac{\partial^{2} M_{x y}^{\prime}}{\partial x \partial y} \\
+N_{y}{ }^{F} \frac{\partial^{2} w}{\partial y^{2}}+\frac{1}{R} N_{y}^{\prime}=0
\end{array}
$$

境界条件としては次のようなローラー支持に近い，古 典的単純支持を採用する。

$$
\begin{gathered}
w=\frac{\partial^{2} w}{\partial x^{2}}=\frac{\partial u}{\partial x}=v=0 \quad \text { at } \quad x=0, L \\
w=\frac{\partial^{2} w}{\partial y^{2}}=u=\frac{\partial v}{\partial y}=0 \quad \text { at } \quad y=0, R \phi
\end{gathered}
$$

(14)式は來屈変位 $(u, v, w)$ 飞対して同次式であり， その固有值問題を解くことで座届荷重 $q_{c}$ と座屈モード $(u, v, w)$ を求めるととがでをる。(15)式の境界条件の もとでは，本問題では極めて簡単な形の解が容易に計算 できる。すなわち，座届モードについては，

$$
\begin{gathered}
u=\bar{u}_{m n} \frac{L t}{R} \cos \left(\frac{m \pi x}{L}\right) \sin \left(\frac{n \pi y}{R \phi}\right) \\
v=\bar{v}_{m n} \frac{L t}{R} \sin \left(\frac{m \pi x}{L}\right) \cos \left(\frac{n \pi y}{R \phi}\right) \\
w=\bar{w}_{m n} t \sin \left(\frac{m \pi x}{L}\right) \sin \left(\frac{n \pi y}{R \phi}\right)
\end{gathered}
$$

ただし，

$$
\begin{aligned}
& \bar{u}_{m n}=\bar{w}_{m n} \frac{A_{5} A_{2}-A_{3} A_{4}}{A_{1} A_{4}-A_{2}{ }^{2}} \\
& \bar{v}_{m n}=\bar{w}_{m n} \frac{A_{2} A_{3}-A_{1} A_{5}}{A_{1} A_{4}-A_{2}{ }^{2}}
\end{aligned}
$$

$m, n$ はそれぞれ母線方向半波数と円弧方向半波数， $t$ は ラチスシェルの等価殻厚で，更に，

$$
\begin{aligned}
& A_{1}=C_{x} m^{2}+C_{x y} B^{2}, \quad A_{2}=\left(C_{p}+C_{x y}\right) m B, \\
& A_{3}=\frac{C_{p} m}{\pi}, \quad A_{4}=C_{x y} m^{2}+C_{y} B^{2}, \quad A_{5}=C_{y} \frac{B}{\pi}
\end{aligned}
$$

である。

一方, 座届荷重 $q_{c}$ については, 次の(19)式で定義され る係数 $q_{d}$ で正規化すると形状係数や剛性比の倁果が明確 となる。とのとを，(5)式に用いる座届耐力 $Q_{c} は ，$

$$
\begin{gathered}
Q_{c} \equiv \frac{q_{c}}{q_{d}}=Q_{b}+Q_{m} \\
q_{d} \equiv \pi^{2} \frac{D_{y}}{R L^{2}}
\end{gathered}
$$

(18)式における，坐届值の曲げひずみエネルギー成分か ら得られるRS值 $Q_{b}$ と, 面内ひずみエネルギー成分か ら得られる $Q_{m}$ は，次式のよ5に誘導できる。

$$
\begin{gathered}
Q_{b}=B^{2}+2\left(D_{2}+2 D_{3}\right) m^{2}+D_{1} \frac{m^{4}}{B^{2}} \\
Q_{m}=12\left(C_{1}-C_{2}{ }^{2}\right) C_{3} \frac{\beta^{2} m^{4}}{\pi^{4} B^{2} S}
\end{gathered}
$$

ただし，

$$
S=C_{3} B^{4}+\left(C_{1}-C_{2}{ }^{2}-2 C_{2} C_{3}\right) B^{2} m^{2}+C_{1} C_{3} m^{4}
$$

(20)，(21)式中にお々て，正規化円弧方向半波数 $B$, 形 状係数 $\beta$, 等価壳厚 $t$, 岡性比は, 以下のよ ている。

$$
\begin{gathered}
B=\frac{n L}{R \phi} \\
\beta=\frac{L^{2}}{R t} \\
t=\sqrt{12 D_{y} / C_{y}} \\
D_{1}=\frac{D_{x}}{D_{y}}, \quad D_{2}=\frac{D_{p}}{D_{y}}, \quad D_{3}=\frac{D_{x y}}{D_{y}} \\
C_{1}=\frac{C_{x}}{C_{y}}, \quad C_{2}=\frac{C_{p}}{C_{y}}, \quad C_{3}=\frac{C_{x y}}{C_{y}}
\end{gathered}
$$

\section{3 非減衰自由振動数解析の結果と考察}

(16)式の座屈モード $(u, v, w) の m$ と $n$ を任意に変化さ せて得られる集合を, 座届モード群と名づけ, 対応する 非隇衰自由振動モードを次のよらに仮定する。 


$$
\left(u_{d}, v_{d}, w_{d}\right)=(u, v, w) \sin (\omega \tau)
$$

とのとき，速度成分の 2 乗和は，(27)式より

$$
\left(\frac{\partial u_{d}}{\partial \tau}\right)^{2}+\left(\frac{\partial v_{d}}{\partial \tau}\right)^{2}+\left(\frac{\partial w_{d}}{\partial \tau}\right)^{2} \leq \omega^{2}\left(u^{2}+v^{2}+w^{2}\right)
$$

であるので，最大運動エネルギー $T_{2}$ は，

$$
T_{2}=\omega^{2} \frac{q_{w}}{g} \int_{0}^{R \phi} \int_{0}^{L} \frac{1}{2}\left(u^{2}+v^{2}+w^{2}\right) d x d y
$$

ことで，gは重力加速度である。 $q_{w}$ は単位面積当たりの 重量で, 構造設計上は自重や積載や䆊雪による荷重の単 位面積当たりの総量に相当する。エネルギーの正規化係 数を $E_{0} \equiv 12 D_{y} L \phi\left(\bar{w}_{m n}\right)^{2} / R$ とし, 荷重係数を(19)式の $q_{d}$ を用いて $Q_{w} \equiv q_{w} / q_{d}$ と定義し，(28)式の積分を実行する $\varepsilon,(5)$ 式の $\alpha_{t}$ は次のように得られる。

$$
\alpha_{t}=Q_{w} E_{0}\left(\alpha_{t u}+\alpha_{t v}+\alpha_{t w}\right)
$$

ことK $\alpha_{t u}, \alpha_{t v}, \alpha_{t w}$ は, それぞれ $x, y, z$ 方向の慣性力 凡関する(28)式の積分結果である。予備解析を行なった 結果, $\alpha_{t u} 々 \alpha_{t v}$ の自由振動数に及注す影響は, 本節で対 象とする程度の単層のラチスシェル屋根では， $1 \%$ 未満 であるととがわかったので，本研究では簡単のためとれ らを省略すると，

$$
\alpha_{t} \approx E_{0} \alpha_{t w} Q_{w}=E_{0} \frac{\pi^{2} t Q_{w}}{96 g \beta}
$$

一方，線形化された面内ひずみエネルギー成分 $V_{2 m}$ は， 荷重 $q$ を受ける偏平な屋根型の部分円筒ラチスの場合, 近似的飞次のように与えられる。

$$
V_{2 m}=-q R \int_{0}^{R \phi} \int_{0}^{L} \frac{1}{2}\left(\frac{\partial w}{\partial y}\right)^{2} d x d y
$$

(31)式中の $q$ は, 重量 $q_{w}$ K, 建物内外の空気圧力差によ る圧力も加算される必要がある。しかしながら，後者に ついては, 文献[1]での予備的解析の結果, 海面下に没し た構造物などの特殊な環境を想定しない限り，その自由 振動数に与える影響は小さいととがわかったので，本論

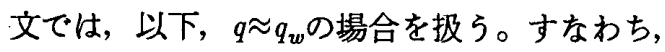

$$
Q \equiv \frac{q}{q_{d}} \approx Q_{w}=\frac{q_{w}}{q_{d}}
$$

(31)式の積分を実行すると(5)式の $\alpha_{m}$ は,

$$
\alpha_{m}=E_{0} \frac{\pi^{4} B^{2}}{96 \beta^{2}}
$$

(30)式と(33)式を(5)式に代入すると，モード $(m, n)$ К関 する固有円振動数 $\omega$ が次のようと得られる。

$$
\omega^{2}=g \pi^{2} B^{2} \frac{Q_{c}-Q}{\beta t Q_{w}}
$$

無次元振動数 $F$ として,

$$
F \equiv \frac{\omega}{2 \pi} \sqrt{\frac{t}{g}}
$$

を採用すると，次式のような極めて単純な形の式を得る ととができる。

$$
F=B \sqrt{\frac{Q_{c}-Q}{4 Q_{w} \beta}}
$$

形状係数 $\beta=96.6$, 剛性比 $C_{1}=1, C_{2}=C_{3}=1 / 3$, $D_{1}=1, D_{2}=0.061, D_{3}=0.469$ の場合の結果を, 図 2 の太実線で示す。との図は，横軸に(22)式の正規化円 弧方向半波数 $B$ を採っているので，任意のアスペクト比 $a=L / R \phi$ 凡対して利用でをる。また，(18)と(20)式か ら $Q_{c}$ は $m$ の 4 乗に比例して大きくなるので, $F か ゙$ 最小と なる $m=1$ の場合のみを例として図示している。図中の $\lambda$ は自重等の静的荷重の大をさを表わす無次元係数で，荷 重係数と呼ぶてととし, 本研究では, 以下として定義さ れている。

$$
\lambda \equiv Q_{w} / Q_{c 0}
$$

ただし， $Q_{c 0}$ は最小座屈値で，静的座屈解析で $B$ を連続 的飞変化させて得られる座届耐力 $Q_{c}$ の最小值を意味する。 乙の最小坐屈值 $Q_{c 0}$ を与元る正規化弧方向半波数 $B_{c 0}$ は,

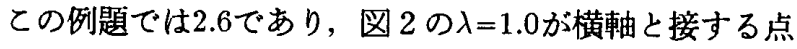
でのBの值に一致している。

一印は, 正規化振動数 $F$ の最小点を明示したもので, 乙の最小値を最小自由振動数 $F_{0}$ と定義し, 有限多自由度 系での 1 次の固有振動数に相当する值を意味する。荷重 係数入が大をくなるにつれ， $F_{0}$ は著しく小さくなるてと が注目される。更に入が增加するとともに， $F_{0}$ をえる 円弧方向半波数 $B_{0}$ も増加しているが, $\lambda>0.1$ の範囲では, その変化の程度はわずかとなっており，座届モードと最 小自由振動モードは，ほば一致するてとがわかる注2)。

細実線は，(3)式において第 4 項の線形化された面内 ひずみエネルギー項 $V_{2 m}=-Q \alpha_{m}$ を省略した場合の結果 で，初期応力の影響を考慮しない従来の自由振動解析結 果に対忍する。とのときの(5)，(36)式に相当する解は,

$$
\begin{gathered}
\omega_{c l}^{2}=Q_{c} \frac{\alpha_{m}}{\alpha_{t}} \\
F_{c l}=B \sqrt{\frac{Q_{c}}{4 Q_{u} \beta}}
\end{gathered}
$$

振動開始前飞存在する初期応力を考慮すると, 本問題の 場合， $\lambda=0.3 て ゙ 14 \% ， \lambda=0.6 て ゙ 33 \%$ 程度と， $F_{0}$ は $\lambda$ が大き くなる程低下率は著しくなり, 初期応力の影響が决して 小さくないてとが明らかになった。

$\bigcirc, \triangle, \square て ゙$ 示した值は，平行して行った有限要素法 


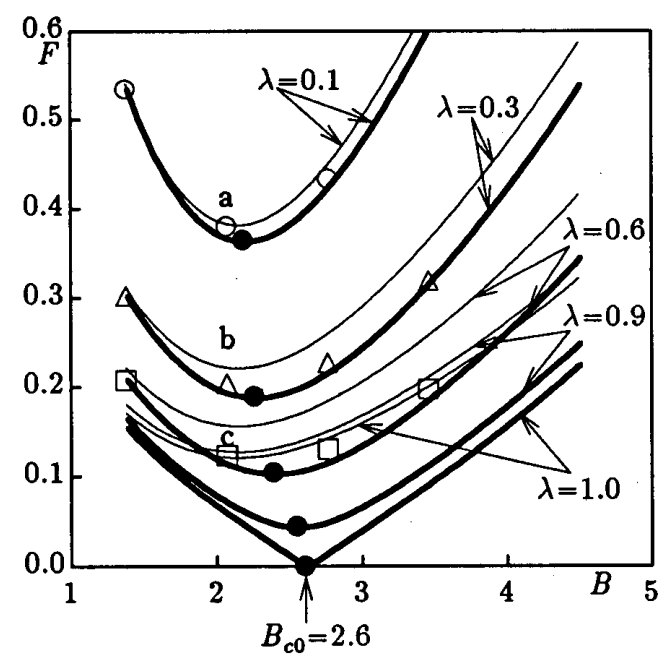

図2 固有振動数に与える初期応力及び荷重係数 の影響

による固有振動解析結果を示す。使用した有限要素振動 解析法の詳細は，既に文献[15]として公表しているもの と全く同一である。具体的な形状寸法等は，先に文献[4] で座屈解析に使用した正三角形ユニット単層ラチスシェ ルのそれと同一とした。本有限要素解析では, アスペク ト比につ々ては, $a=L / R \phi=0.693$ の場合のみを例題 として扱ったので, 横軸 $B=a n の と り$ 得る数值が離散值 となり，自由振動スペクトルは図のような離散スペクト ルとして得られている。尚, 支持条件については, 周辺 に治った支持点が水平に移動可能なローラー支持点とし ているが，コーナーの 4 つの支持点の移動は拘束した。 (36)式による本推定值の太実線と有限要素解 $(\bigcirc \triangle \square)$ とは，手法上の大をな差にもかかわらず， いずれの入に 対しても良く一致している。こうした事実は, 本解析手 法で取入れられている種々の仮定が, 本問題では, 工学 的に妥当な程度になっているととを示していると考察さ れる。

図 3 は, 形状倸数 $\beta$ と剛性比 $C_{1}$ が最小自由振動数 $F_{0} K$ 与える影響について，系統的に解析したものである。母 線方向のラチス部材の断面寸法を他の斜材のそれより小 さくして， $C_{1}$ を図 2 での1.0 (等方性体の場合に相当す る）より小さくすると，(18)式と(21)式から， $Q_{c 0}$ む小さ くなる。しかし，経済設計上の資料となるよら考慮して， 図 3 での入の基準値には， $C_{1}=1.0$ 対して得られる $Q_{c 0}$ を，便宜上 $C_{1}=0.5$ のとをにも採用し整理してみた。そ

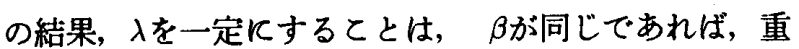
量 $Q_{w}$ も同一であるととを意味し, 剛性比の自由振動数 に与える影響の程度が，より理解しやすい形で図示でき ると考えたからである。形状倸数及の広的範囲で計算さ れて扔り， $\beta$ が大をなる程 $F_{0}$ が小さくなる侕向にある

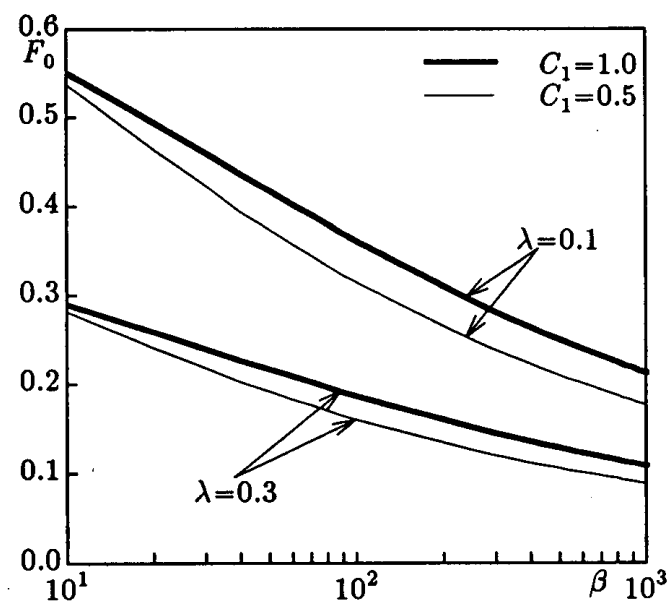

図 3 最小固有振動数に与える各種パラメー ターの影響

と考察される。また，岡性比 $C_{1}$ を1.0から0.5K減少させ ると，扱った $\beta$ 範囲において， $F_{0}$ が 3 から $20 \%$ 程度低 下するととも注目される。

\section{4 初期不整による座届而力の低下が固有振動数に 及ぼす影響について}

図 2 の解析で用いた部分円筒ラチスシェル構造物につ いて，有限要素法により増分法と移動座標法を併用した 幾何学的非線形解析を行々，静的荷重とたわみ関係を求 めた結果が，図 4 a に示されている。形状や部材に関す る諸量は，全て図 2 の場合と同一である。

図中の○印は形状初期不整のない場合であり，2.2 節で論じた荷重不整によって非線形なたわみ性状を示し， その座屈耐力は前節で求められた $Q_{c 0}$ より大きく低下し ている。形状初期不整 $w^{0}$ は，モード $(m, n)=(1,2)$ と $(m, n)=(1,3)$ の波数成分を組み合わせて，

$$
w^{0}={\overline{w^{0}}}_{12} t \sin \frac{\pi x}{L} \sin \frac{2 \pi y}{R \phi}+{\overline{w^{0}}}_{13} t \sin \frac{\pi x}{L} \sin \frac{3 \pi y}{R \phi}
$$

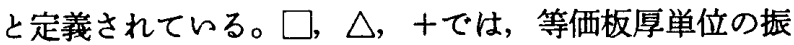
幅 $\bar{w}_{12}, \bar{w}_{13}^{\mathrm{a}}$ は,

$$
\begin{aligned}
& \square \text { では, }{\overline{w^{0}}}_{12}=+0.097, \bar{w}_{13}^{0}=-0.580 \\
& \triangle \text { では, }{\overline{w^{0}}}_{12}=+0.097,{\overline{w^{0}}}_{13}=-0.290 \\
& \text { 十では， } \bar{w}_{12}^{0}=+0.097, \bar{w}_{13}^{0}=+0.097
\end{aligned}
$$

尚， ×印は最初に表われる極大点で，非線形解析による

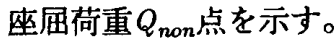

困 4 a 中の $(\Delta \square \bigcirc+)$ の点として明示した種々の荷重 レベル $Q$ を，先ず静的に載荷する。その静的釣合状態の もとで非減哀微小自由振動が生ずるとし，有限要素解析 して得られた 1 次の固有自由振動数の正規化量 $F$ を，横 


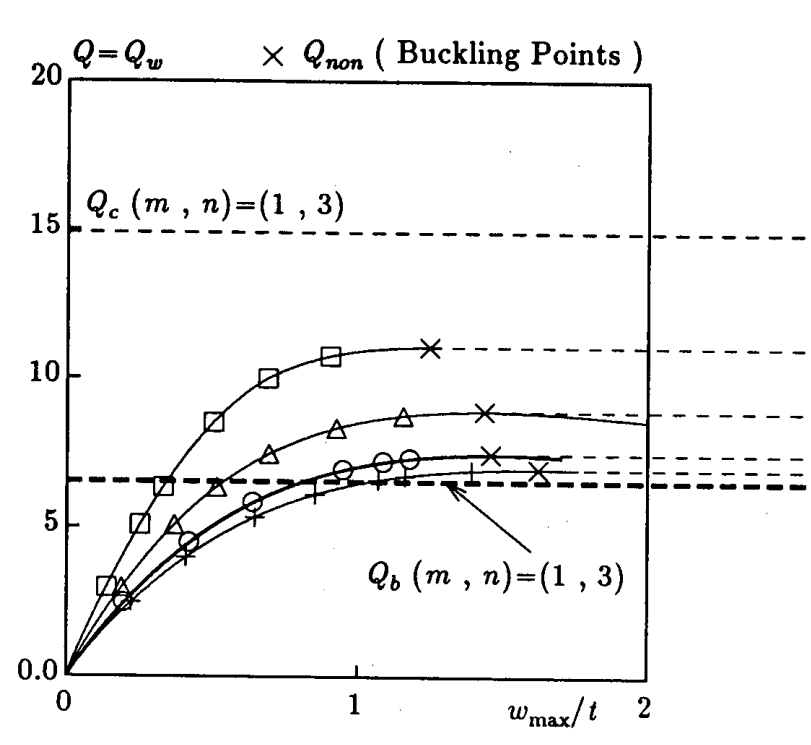

（a）有限要素法による静的非線形たわみ曲線

(b) $(m, n)=(1,3)$ K対する $Q-F_{r}$ 曲線

図 4 ローラー支持された部分円筒ラチスシェルの静的・動的解析例

軸にとって，綖軸QK対してプロットしたのが図 $4 \mathrm{~b}$ の

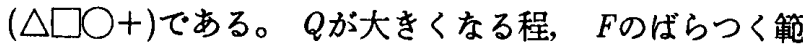
囲が大きくなるととがわかる。本研究では，てらした有 限要素法による結果を, 適当に仮定された初期不整に対 する数值実験結果と位置づける。

一方, 図 4 b の細ら実線は, 図 4 a で×印として示さ れている有限要素法による弾性座屈耐力 $Q_{\text {non }}$ を, (9)式 の $Q_{r}$ K読みかえて， $(m, n)=(1,3)$ 亿対して得た曲線 である。種々の仮定を含んだ簡易式であるにもかかわら ず， $Q_{r}$ を精密解 $Q_{\text {non }}$ として採用すれば，有限要素法によ る数值解析結果 $(\Delta \square O+)$ K，それぞれ，定量的に良く 一致するととを示している。

(9)式の $Q_{r}$ として，(20)式で計算されるR S 座届下限 值 $Q_{b}$ を採用すると, 図 $4 \mathrm{~b}$ の太実線として得られる。 先に 2.2 節で論じたようK，R S 值は，初期不整を等 価款厚程度に大きくしたときの弾性座屈耐力の下限を与 えるととが期待できるので，それを $Q_{r}$ とて採用するて とによって, 初期不整の存在のためにばらつく自由振動 数 $F_{r}$ の下限を得るととができると期待される。図 $4 \mathrm{~b} の$ 本手法での結果(太実線)は, 数值解析結果 $(\triangle \square \mathrm{O}+)$ の近似的な下限を与えているととが注目される注3)。尚， 図 $4 \mathrm{~b}$ での破線は，(5)式を基として得られた(36)式のF であり, 数值解析結果 $(\triangle \square \bigcirc+)$ の上限となっている。 また, 印の $\mathrm{a}, \mathrm{b}, \mathrm{c}$ は, 図 2 で示す $\mathrm{a}(\bigcirc ; \lambda=0.1)$, $\mathrm{b}(\triangle ; \lambda=0.3), \mathrm{c}(\square ; \lambda=0.6)$ K各々対応する值をプロ ットしたもので, 線形の有限要素解析結果を示している。

\section{4. 結 語}

初期応力を考慮したシェル的構造物の自由振動数を単 純かつパラメトリックに推定する手法について提案を行 った。振動性:状に及济す各種パラメータの影響は， (5) 式を用いると比較的容易飞検討できるてとを論じ，具体 的に部分円筒ラチスシェルに適用した結果，(36)式のよ ら火陽な形の式として自由振動数の近似推定式を得られ るととが明らかになった。との種の構造物で避けるとと のできない初期不整の影響については，(9)式を用いる ととにより, 座屈耐力低下に伴ら自由振動数の低下の程 度を，定量的《推定できる可能性が示された。(9)式で 用いる座届耐力 $Q_{r}$ の評価には非線形解析を必要とし, 一 般的な設計の初期段階には必ずしも便利ではないが，線 形 R S 解析で得られる R S 值 $Q_{b}$ を $Q_{r}$ として採用すると とによって, 初期不整によってばらつく自由振動数の下 限が推定でをることを，限られた条件での例題に対して ではあるが，明らかにできた。

本研究は, シェルならびにシェル的ラチス屋根構造の 耐震設計上の観点からは, 非減衰自由振動性状といら, 重要ではあるが極めて基礎的でかつ限定された内容にと どまっている。しかし，本研究で提案された力学的解析 モデルを，モーダルアナリシスとの併用によって強制振 動解析火応用するととも可能であると考えられ，てれに よって強震時の応答の上限值等の評価を得ることがでを ると期待される。とうした興味深的題については，今 後の研究課題とする。 


\section{参考文献}

1)竹内明子, 山田聖志 : 初期応力を考慮したラチスシェ ルの自由振動評価手法, 日本建築学会大会学術講演梗 概集, Vol.B, pp.1349-1350, 1993.9

2) 日㯰興一郎(編) : 単層ラチスドームの安定解析, 日本 建築学会シェル空間構造運営委員会, 1989.8

3) Seishi Yamada and J.G.A. Croll: Buckling behavior of pressure loaded cylindrical panels, Journal of Engineering Mechanics, ASCE, Vol.115, No.2, pp.327-344, 1989.2

4) Seishi Yamada: Relationship between non-linear numerical experiments and a linear lower bound analysis using finite element method on the overall buckling of reticular partial cylindrical space frames, Computer Applications in Civil and Building Engineering, Kozo System Inc., pp.259-266, 1991.11

5)D.E. Newland: Mechanical Vibration Analysis and Computation, Longman Group UK Ltd, London, 1989

6) Seishi Yamada and T. Taguchi: Nonlinear buckling response of latticed barrel vaults, Spacial, Lattice and Tension Structures, Proc. IASS-ASCE Symp., ASCE, pp.519-528, 1994.4

7)J.G.A. Croll: Elasto-plastic buckling of pressure and axial loaded cylinders, Proc. Instn Civil Engrs, Vol.73, pp.633-652, 1982

8)山田聖志 : 座届前飞幾何学的非線形性を有するシェル 構造物への R S 法の適用，日本建築学会棈造系論文報 告集, No.390, pp.88-97, 1988.8

9) Seishi Yamada and J.G.A. Croll: Buckling and postbuckling characteristics of pressure loaded cylinders, Journal of Applied Mechanics, ASME, Vol.60, pp.290-299, 1993.6

10)Seishi Yamada and J.G.A. Croll: Elasto-plastic buckling design for shallow cylindrical shells under external pressure, Spacial, Lattice and Tension Structures, Proc. IASS-ASCE Symp., ASCE, pp.936-945, 1994.4

11)L.N. Virgin: Postbuckling dynamics of struts as Related to their loading devices, Engrg Struct., Vol.8, pp.127-133, 1986

12)山田大彦: 連続体近似による単層ラチスドームの坐 届耐力の詸価につんて, 単層ラチスドームの安定解析, 日本建築学会, pp.191-254, 1989.8

13)K. Heki: On the effective rigidities of lattice plates; Recent Researches of Structural Mechanics, Uno Shoten, Tokyo, pp.31-46, 1968
14)J. Sumec: Regular Lattice Plates and Shells, Elsevier, 1990

15)山田聖志 : 屋根型円筒ラチス, シェル・単層ラチス構 造の振動解析, 日本建築学会, pp.95-117, 1993.8

16)L.N. Virgin: The dynamics of symmetric postbuckling, Int. J. Mech. Sci., Vol.27, pp.235-248, 1985

\section{付録 剛性成分の計算}

等価岡性の計算は, 文献[13],[14] を参考に, 以下の よ5に行なった。まず，付図のよ5に $1 ， 2 ， 3$ 方向の 部材から全体が構成されているものとみなし, 各部材 につレてローカル座標系 $(\xi, \eta)$ を考える。

\section{i) 応力 - ひずみ関係}

面内合応力 $\left\{N_{\xi}\right\}$ Kつては，各方问の部材でとに， 一次元のはり要素とみなしているので,

$$
\left\{\begin{array}{c}
N_{\xi} \\
N_{\eta} \\
N_{\xi \eta}
\end{array}\right\}=\left[\begin{array}{ccc}
E A / l^{\prime} & 0 & 0 \\
0 & 0 & 0 \\
0 & 0 & 0
\end{array}\right]\left\{\begin{array}{c}
\varepsilon_{\xi} \\
\varepsilon_{\eta} \\
\gamma_{\xi \eta}
\end{array}\right\}
$$

簡単のため,

$$
\left\{N_{\xi}\right\} \equiv\left[E_{\xi}\right]\left\{\varepsilon_{\xi}\right\}
$$

と略寸。ととK，Eはヤング係数であり，Aは部材断 面積， l'は部材間隔である。

曲げモーメント $\left\{M_{\xi}\right\}$ について, $M_{\xi \eta}=M_{\eta \xi}=G J / 2 l^{\prime}$ とし, $\kappa_{\xi \eta}=\rho_{\xi \eta}+\rho_{\eta \xi}$ とすると,

$$
\left\{\begin{array}{c}
M_{\xi} \\
M_{\eta} \\
M_{\xi \eta}
\end{array}\right\}=\left[\begin{array}{ccc}
E I / l^{\prime} & 0 & 0 \\
0 & 0 & 0 \\
0 & 0 & G J / 4 l^{\prime}
\end{array}\right]\left\{\begin{array}{c}
\rho_{\xi} \\
\rho_{\eta} \\
\kappa_{\xi \eta}
\end{array}\right\}
$$

簡単のため,

$$
\left\{M_{\xi}\right\} \equiv\left[D_{\xi}\right]\left\{\rho_{\xi}\right\}
$$

と略す。尚, 本研究では, 構成部材にパイプ材を用い ており, せん断剛性 $G=E / 2.6$ ねでり剛性 $J=2 I$, 断

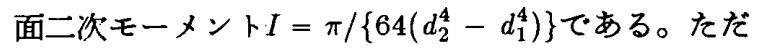
し， $d_{2}, d_{1}$ は，それぞれパイプの外径と内径である。

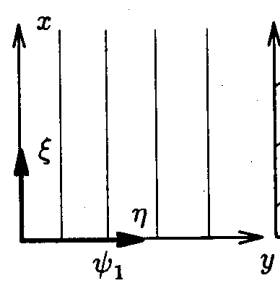

( 1 方向 )

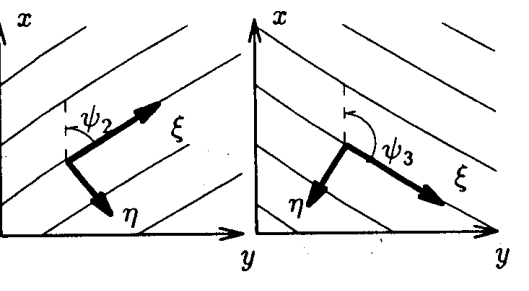

( 2 方向 ) ( 3 方向 ) 付図 部材坐標系 $(\xi, \eta)$ の定義 


\section{ii) 全体座標系への变換}

i)で定めた円筒ラチスシェルを直交異方性とし， $i=1,2 ， 3$ 方向それぞれのローカル座標 $(\xi, \eta)$ を，反時 計回りに $\psi_{i}$ だけ回転した全体座標 $(x, y)$ で剛性を䚵価 する。とのとき，応力の座標変換は，

$$
\left\{\sigma_{x}\right\} \equiv\left\{\begin{array}{c}
\sigma_{x} \\
\sigma_{y} \\
\sigma_{x y}
\end{array}\right\}=[A]\left\{\begin{array}{c}
\sigma_{\xi} \\
\sigma_{\eta} \\
\sigma_{\xi \eta}
\end{array}\right\} \equiv[A]\left\{\sigma_{\xi}\right\}
$$

ただし，

$$
[A]=\left[\begin{array}{ccc}
\cos ^{2} \psi_{i} & \sin ^{2} \psi_{i} & 2 \sin \psi_{i} \cos \psi_{i} \\
\sin ^{2} \psi_{i} & \cos ^{2} \psi_{i} & -2 \sin \psi_{i} \cos \psi_{i} \\
-\sin \psi_{i} \cos \psi_{i} & \sin \psi_{i} \cos \psi_{i} & \cos ^{2} \psi_{i}-\sin ^{2} \psi_{i}
\end{array}\right]
$$

一方,ひずみの座標変換につレては,

$$
\left\{\varepsilon_{x}\right\} \equiv\left\{\begin{array}{c}
\varepsilon_{x} \\
\varepsilon_{y} \\
\gamma_{x y}
\end{array}\right\}=[B]\left\{\begin{array}{c}
\varepsilon_{\xi} \\
\varepsilon_{\eta} \\
\gamma_{\xi \eta}
\end{array}\right\} \equiv[B]\left\{\varepsilon_{\xi}\right\}
$$

ただし

$$
[B]=\left[\begin{array}{ccc}
\cos ^{2} \psi_{i} & \sin ^{2} \psi_{i} & \sin \psi_{i} \cos \psi_{i} \\
\sin ^{2} \psi_{i} & \cos ^{2} \psi_{i} & -\sin \psi_{i} \cos \psi_{i} \\
-2 \sin \psi_{i} \cos \psi_{i} & 2 \sin \psi_{i} \cos \psi_{i} & \cos ^{2} \psi_{i}-\sin ^{2} \psi_{i}
\end{array}\right]
$$

全体座標系における要素面内剛性マトリクス $\left[E_{x}(i)\right]$ を 算出すると，

$$
\left\{\sigma_{x}\right\}=[A]\left[E_{\xi}\right][B]^{-1}\left\{\varepsilon_{x}\right\} \equiv\left[E_{x}(i)\right]\left\{\varepsilon_{x}\right\}
$$

全体座標系における要素曲げ剛性マトリクス $\left[D_{\boldsymbol{x}}(i)\right]$ を 算出すると

$$
\left\{M_{x}\right\}=[A]\left[D_{\xi}\right][B]^{-1}\left\{\rho_{x}\right\} \equiv\left[D_{x}(i)\right]\left\{\rho_{x}\right\}
$$

iii) 全体座標系での全体剛性マトリクス

ii)で得られた $1 ， 2 ， 3$ 方向の剛性を重ね合わせて全 体剛性、トリクス $\left[E_{X}\right]$ 及び $\left[D_{X}\right]$ を求める。即ち,

$$
\begin{aligned}
& {\left[E_{X}\right]=\sum_{i=1}^{3}\left[E_{x}(i)\right] \equiv\left[\begin{array}{ccc}
C_{x} & C_{p} & 0 \\
C_{p} & C_{y} & 0 \\
0 & 0 & C_{x y}
\end{array}\right]} \\
& {\left[D_{X}\right]=\sum_{i=1}^{3}\left[D_{x}(i)\right] \equiv\left[\begin{array}{ccc}
D_{x} & D_{p} & 0 \\
D_{p} & D_{y} & 0 \\
0 & 0 & D_{x y}
\end{array}\right]}
\end{aligned}
$$

ととで，各 方向部材の断面積を $A_{i}$, 及び断面二次モ 一メントを $I_{i}$ とし，母線方向 $(i=1)$ 部材の值を基準とし て整理するために,

$$
A_{1}=A, \quad A_{2}=A_{3} \equiv a^{\prime} A, \quad I_{1}=I, \quad I_{2}=I_{3} \equiv b^{\prime} I
$$

と定義する。本研究のような正三角形のメッシュパタ ーンでは, $\psi_{i}=0, \pi / 3,2 \pi / 3$ なので, (ii-3)式と (ii-4)式より, (iii-1)式の各成分は以下のよ5に計算 される。

$$
\begin{aligned}
& C_{x}=\left(8+a^{\prime}\right) K_{0}, C_{p}=3 a^{\prime} K_{0}, \\
& C_{y}=9 a^{\prime} K_{0}, C_{x y}=3 a^{\prime} K_{0}, \\
& D_{x}=\left\{8+b^{\prime}(1+12 d)\right\} D_{0}, D_{p}=3 b^{\prime}(1-4 d) D_{0}, \\
& D_{y}=3 b^{\prime}(3+4 d) D_{0}, D_{x y}=\left\{8 d+b^{\prime}(3+4 d)\right\} D_{0}
\end{aligned}
$$

ただし, $K_{0} \equiv \sqrt{3} E A /\left(12 l_{e}\right), \quad D_{0} \equiv \sqrt{3} E I /\left(12 l_{e}\right)$, $d=G J /(4 E I) ， l_{e}$ は部材長である。

\section{注}

注1）（6)式において $Q / Q_{r}$ はから1までの実数で，次 式のようと展開できる。

$$
w_{m n}^{r} \approx w_{m n}^{0}\left(\frac{Q}{Q_{r}}+\left(\frac{Q}{Q_{r}}\right)^{2}+\cdots+\left(\frac{Q}{Q_{r}}\right)^{k}\right)
$$

とれを(7)式に代入して，(8)式の条件を用的ると

$$
a_{0}=\omega^{2}, \quad a_{1}=-\omega^{2} /\left(w_{m n}^{0} k\right)^{2}
$$

と形式的に求まるので，(7)式より

$$
\omega_{r}^{2}=\omega^{2}-\left(\frac{\omega}{k}\right)^{2}\left(\frac{Q}{Q_{r}}+\left(\frac{Q}{Q_{r}}\right)^{2}+\cdots+\left(\frac{Q}{Q_{r}}\right)^{k}\right)^{2}
$$

$k$ をいくらとするかで各種の不整型～～S モデルが可能 であるが，最も簡単な例として，本論文では $k=1$ の場 合を選び (9)式を導いている。その結果, 初期不整に よって坐届耐力が $Q_{c}$ から $Q_{r}$ 一低下するととは考虑し ているが， $k$ を 2 以上とした際に可能な非線形の復元力 効果については対象としていない。非線形振動応答の 為のモデル化には, 更に検討する必要がある。

注2）形状寸法が全て固定された条件では, アスペク 卜比 $a$ が一定であるため, 図 2 の横軸 $B$ は離散的な值 のみをとる。しかし, 文献[8],[3] で論じられているよ 5K，連続体の部分円筒シェルK対する幾何学的非線 形静的解析では，座屈荷重時の増分変位モードの波長 加逆算して得られる円弧方向半波数 $n$ は, 固有値解 析での半波数 $n$ を形式的に連続量とみなした値に近い てとが示されている。そてで，てらした既往の成果を ふまえ，本研究でも， $n$ を正規化した值 $B$ をあたかも 連続的にとりえる量として力学的分析を行っている。 注3） $\vec{w}_{13}{ }^{\mathrm{d}}$ を, 正でより大をな值にとり, 静的非線形 解析を行らと, 座届は生じなくなる。そのため, 初期 応力による自由振動数 $F$ の低下は抑制され，結果とし て, 図 $4 \mathrm{~b}$ の太実線はそれら反対しても概略の下限值 を与えることが予備的計算で碓かめられている。この 事実は，文献[16]での初期不整を有するリンク構造モ デルイ対する解析結果と定性的によく対応している。 (1994 年 3 月 3 日原稿受理, 1994 年 8 月 25 日採用決定) 